\title{
ARTIKELEN
}

\section{Gemeenten organiseren kleinschaligheid: binnengemeentelijke organisatie opnieuw bekeken}

\author{
Linze Schaap \& Gert-Jan Leenknegt
}

\begin{abstract}
Het overgrote deel van de Nederlandse gemeenten organiseert een deel van haar activiteiten op kleinere schaal dan die van de gemeente als zodanig: binnengemeentelijk organisatie. In dit artikel wordt de bestaande kennis over de effecten van diverse vormen van binnengemeentelijk organiseren in Nederland geïnventariseerd. Op basis van recent onderzoek wordt die kennis aangevuld en wordt tevens inzichtelijk gemaakt welke vormen van binnengemeentelijke organisatie momenteel voorkomen. Ook wordt geanalyseerd welke juridische ruimte gemeenten in dezen hebben. Tevens wordt een nieuwe en rijkere typologie van binnengemeentelijk organiseren ontwikkeld. Tot slot plaatsen de auteurs de resultaten van het hier gerapporteerde onderzoek in een breder perspectief. In het bijzonder wordt gereflecteerd op twee vooronderstellingen onder veel vormen van binnengemeentelijk organiseren, namelijk dat activiteiten plaatsgebonden zijn en dat de democratie per se van het 'vertegenwoordigende' type moet zijn.

Relevantie voor practitioners: dit artikel biedt inzicht in (a) de juridische ruimte voor binnengemeentelijke organisatie en $(b)$ de vormgeving van binnengemeentelijke organisatie, en bevat (c) een reflectie op de vormgeving van binnengemeentelijke organisatie.
\end{abstract}

\section{Inleiding ${ }^{1}$}

Veel gemeenten organiseren een deel van hun taken op een kleinere schaal dan de gemeente als geheel. Dit is een fenomeen dat zich al decennia lang voordoet, maar de kennis hierover in Nederland is gefragmenteerd (bijvoorbeeld onderzoek naar één of enkele vormen van binnengemeentelijke organisatie; zie Necker van Naem, 2013) en verouderd (WRR,1998; Berenschot, 2001). Daarnaast is er wel internationale kennis (bijvoorbeeld Bäck e.a., 2005) en is die soms vertaald naar de Nederlandse situatie (bijvoorbeeld Denters \& Klok, 2013; Schaap e.a., 2013). Meer aandacht voor binnengemeentelijk organiseren is geboden. De eerste reden daarvoor is dat er vele vormen van binnengemeentelijke organisatie bestaan en

1 Dit artikel is mede gebaseerd op een onderzoek dat de auteurs voor het ministerie van Binnenlandse Zaken en Koninkrijksrelaties hebben uitgevoerd; zie Schaap \& Leenknegt, 2018. Zij zijn Julien van Ostaaijen erkentelijk voor de medewerking daaraan. 
dat gemeenten dus zonder stevige kennis over de effecten van al die vormen keuzes maken. Zo kan binnengemeentelijk organiseren betrekking hebben op vele vormen (bijvoorbeeld wel of niet verkiezing van de betrokkenen), verschillende soorten activiteiten (zoals adviseren en/of uitvoeren) en diverse betrokkenen (burgers, maatschappelijke organisaties, ambtenaren, politici, al of niet in combinatie). De tweede reden is dat het lokaal bestuur en de lokale democratie nogal in beweging zijn (zie bijvoorbeeld Boogers \& Reussing, 2018; Schaap e.a., 2018). Zo hebben de recente decentralisaties een groot beroep gedaan op de bestuurskracht van gemeenten; binnengemeentelijk organiseren kan daar een reactie op zijn. Daarnaast zoeken veel gemeenten naar aanvullende vormen van democratie en ook die wordt veelal op binnengemeentelijk niveau gezocht. Maar in beide gevallen is het onzeker of binnengemeentelijk organiseren werkelijk tot de bedoelde positieve resultaten leidt. ${ }^{2}$

Met dit artikel hebben wij vier doelen. In de eerste plaats willen we de bestaande kennis over de effecten van diverse vormen van binnengemeentelijk organiseren in Nederland inventariseren. In de tweede plaats vullen we de kennis over de vormgeving van binnengemeentelijke organisatie aan op basis van een recent door ons uitgevoerd onderzoek. Een derde doel is het bespreken van het juridisch kader voor binnengemeentelijke organisatie. Immers: Grondwet en Gemeentewet bepalen de ruimte die gemeenten juridisch hebben voor overdracht van taken en bevoegdheden aan andere organen. Tot slot plaatsen wij de resultaten van het hier gerapporteerde onderzoek in een breder perspectief.

Wij zoeken hier een antwoord op de vraag: 'Wat is de stand van zaken met betrekking tot binnengemeentelijke organisatie in Nederland, en in hoeverre belemmeren wettelijke bepalingen het zoeken naar adequate binnengemeentelijke oplossingen voor schaalvraagstukken?' In het onderliggende onderzoek (Schaap \& Leenknegt, 2018) zijn we op zoek gegaan naar vormen van binnengemeentelijke organisatie, redenen voor de gemaakte keuzes, effecten, en voor- en nadelen van de diverse vormen. In dit artikel ligt de nadruk op de vormen en de effecten van elk daarvan (voor zover bekend). Ten aanzien van die 'effecten' merken we op dat daarbij wel sprake is van een verband met het instellen van binnengemeentelijke organisatie, maar dat het beschikbare materiaal over het algemeen geen harde conclusies rechtvaardigt over de directe effecten.

\section{Aanpak}

Het eerste deel van het onderliggende onderzoek (Schaap \& Leenknegt, 2018) bestond uit een systematische en uitgebreide literatuurverkenning van Nederlandstalige publicaties van na 2000, met als trefwoorden: binnengemeentelijk(e) (organisatie, bestuur, decentralisatie, deconcentratie), binnenstedelijk (bestuur), dorpsraden, wijkraden, deconcentratie gemeente, wijkkantoren, wijkgericht (werken), dorpenbeleid, buurtparticipatie, buurt bestuurt, wijkparticipatie, bestuurs-

2 Zo bleek uit een zeer recent - na afronding van de tekst van dit artikel - verschenen rapport van het Centraal Planbureau dat werken met wijkteams in het sociaal domein eerder tot meer dan tot minder dure zorg leidt; zie CPB, 2019. 
model (gemeente). Daarnaast is in de juridische literatuur en in de laatste vijf jaargangen van de tijdschriften Bestuurskunde en Bestuurswetenschappen afzonderlijk gezocht naar kennis over binnengemeentelijke organisatie. Uit het verzamelde materiaal is een rijke en nieuwe typologie gemaakt.

Vervolgens is een online enquête uitgezet onder de gemeentesecretarissen van alle 388 gemeenten (telling 2017). In een e-mail van het tijdschrift Binnenlands Bestuur ontvingen zij daartoe een uitnodiging van het ministerie van Binnenlandse Zaken en Koninkrijksrelaties (opdrachtgever van het onderzoek). De mogelijkheid werd geboden om de e-mail door te sturen naar een ter zake deskundige medewerker. Om de respons te verhogen is tweemaal een herinnering gestuurd. Uiteindelijk heeft $28 \%$ van de aangeschreven gemeentesecretarissen de vragenlijst ingevuld, in driekwart van de gevallen volledig. De deelnemende gemeenten zijn divers van karakter (zowel qua inwonertal als aantal kernen).

Op basis van de literatuur en de enquêtegegevens is vervolgens gezocht naar patronen en naar effecten van de diverse typen binnengemeentelijke organisatie. Wij hebben ervoor gekozen ons te concentreren op de effecten op zowel de gemeentelijke bestuurskracht (in de zin van het vermogen van de gemeente om haar opgaven te kennen, die om te zetten in concreet beleid, die opgaven te formuleren en te vertalen in interactie met de samenleving, het beleid effectief en efficiënt uit te (doen) voeren en te laten resulteren in zichtbare maatschappelijke effecten) als de lokale democratie (wat betekent binnengemeentelijke organisatie voor de positie van de raad en voor burgerparticipatie). Die twee typen effecten blijken voor gemeenten in veel Europese landen de redenen te zijn om over te gaan tot binnengemeentelijke organisatie, in het bijzonder het instellen van dorps- en wijkraden (Denters \& Klok, 2013). Voor het onderzoek naar patronen is onder meer gekeken naar gemeentegrootte en de vraag of de gemeente wel of niet het gevolg is van een gemeentelijke herindeling.

\section{Typologie van binnengemeentelijke organisatie}

In Nederlandse studies over binnengemeentelijke organisatie is het niet ongebruikelijk om een tweedeling aan te brengen (zie bijvoorbeeld WRR, 1998; Berenschot, 2001; Cachet e.a., 2003; Schaap, 2015). De ene vorm is dan binnengemeentelijke (of bestuurlijke) decentralisatie: de gemeente draagt taken, bevoegdheden en middelen over aan een rechtstreeks gekozen volksvertegenwoordiging op een kleiner schaalniveau. De tweede onderscheiden vorm is binnengemeentelijke (of ambtelijke) deconcentratie: de politieke en bestuurlijke structuur in de gemeente blijft onveranderd, maar er worden ambtelijke diensten in het leven geroepen voor specifieke geografische delen van de gemeente. Dit onderscheid negeert echter de variëteit die zich in de bestuurspraktijk voordoet.

Als we naar de internationale literatuur kijken, en dan vooral de veelvuldig aangehaalde studie van Bäck e.a. (2005; zie ook Denters \& Klok, 2013), dan zien we al meteen dat een tweedeling te grofmazig is. Bäck e.a. vergeleken vormen van bin- 
nengemeentelijke decentralisatie aan de hand van vijf criteria: territorium, multifunctionaliteit, politiek bestuur, verantwoordelijk voor dienstverlening en afgeleid bestuur. Deze typologie is niet kraakhelder. Drie van de vijf criteria zijn dichotoom en definiërend van karakter: een organisatie is wel of niet territoriaal, draagt wel of niet de verantwoordelijkheid voor dienstverlening en haar status en bevoegdheden zijn wel of niet afgeleid van het gezag van een ander bestuur. Maar 'multifunctionaliteit' kan vele vormen aannemen (immers: op hoeveelheid beleidsvelden is de organisatie actief, en is zij verantwoordelijk voor beleid, uitvoering, advisering, of voor combinaties daarvan?). Het criterium 'politiek bestuur' is zo mogelijk nog minder eenduidig. Er is dan sprake van een 'besluitvormend' orgaan, maar niet per se van een orgaan dat beleidsbeslissingen neemt; de leden van dat orgaan kunnen door de inwoners van het desbetreffende deel van de gemeente worden gekozen of zij worden - partijpolitiek - benoemd door de gemeenteraad (in welk geval het twijfelachtig is of we hier nog te maken hebben met een decentraal orgaan).

Om deze problemen te ondervangen hebben Schaap e.a.. (2013) geprobeerd een duidelijker onderscheid te maken tussen de mogelijke taken van een decentraal orgaan en de mogelijke samenstelling van het orgaan. Zij kwamen tot vijf vormen van binnengemeentelijke organisatie. Maar op de keper beschouwd is ook een vijfdeling een simplificatie. Als het gaat om aspecten van beleidsvorming, kunnen we ten minste denken aan (mee)beslissen, uitvoeren en adviseren. Actoren aan wie taken en bevoegdheden worden overgedragen, kunnen raadsleden, wethouders, ambtenaren, burgers, vertegenwoordigers van maatschappelijke instellingen en bedrijven zijn. Al die actoren kunnen betrokken zijn bij vrijwel alle van de hiervoor genoemde aspecten van beleidsvorming. Als we dat alles verdisconteren in een typologie, dan resulteert dat in een veelheid aan vormen van binnengemeentelijke organisatie (of eigenlijk: binnengemeentelijk 'organiseren'); zie de kadertekst.

\section{Kadertekst: Onderscheiden vormen van binnengemeentelijke organisatie}

Vormen van binnengemeentelijke organisatie

Hoofdvorm: Politieke binnengemeentelijke organisatie

A. Politieke binnengemeentelijke besluitvorming: direct gekozen politici (niet zijnde leden van de gemeenteraad) die besluiten nemen over strategie, beleid en/of budget voor een bepaald deel van de gemeente.

B. Politieke binnengemeentelijke uitvoering: direct gekozen politici (niet zijnde leden van de gemeenteraad) die besluiten nemen over uitvoering van gemeentebeleid voor een bepaald deel van de gemeente.

C. Politieke binnengemeentelijke advisering: direct gekozen politici (niet zijnde leden van de gemeenteraad) die namens een bepaald deel van de gemeente het gemeentebestuur adviseren.

D. Meervoudige politieke binnengemeentelijke organisatie: direct gekozen politici (niet zijnde leden van de gemeenteraad) die namens een bepaald deel van de gemeente verschillende taken combineren (strategie/beleid/budgetten, uitvoering, advisering). 
Hoofdvorm: Bestuurlijke binnengemeentelijke organisatie

E. Bestuurlijke binnengemeentelijke besluitvorming: wethouders die uitdrukkelijk besluiten nemen over strategie, beleid en/of budget voor een bepaald deel van de gemeente, zoals wijkwethouders.

F. Bestuurlijke binnengemeentelijke uitvoering: wethouders of raadscommissies die verantwoordelijk zijn voor de uitvoering van gemeentebeleid in een bepaald deel van de gemeente.

G. Bestuurlijke binnengemeentelijke advisering: raadscommissies en/of raadsleden die aangewezen zijn om te adviseren over een bepaald deel van de gemeente.

$\mathrm{H}$. Meervoudige bestuurlijke binnengemeentelijke organisatie: wethouders en/of raadscommissies die voor een bepaald deel van de gemeente verschillende taken combineren (strategie/beleid/budgetten, uitvoering, advisering).

Hoofdvorm: Ambtelijke binnengemeentelijke organisatie

I. Ambtelijke binnengemeentelijke besluitvorming: speciaal aangewezen ambtenaren/organisatieonderdelen die in een bepaald deel van de gemeente besluiten nemen over strategie/ beleid/budget voor dat gebied.

J. Ambtelijke binnengemeentelijke uitvoering: speciaal aangewezen ambtenaren/organisatieonderdelen die in een bepaald deel van de gemeente uitvoerende werkzaamheden verrichten.

K. Meervoudige ambtelijke binnengemeentelijke organisatie: speciaal aangewezen ambtenaren/organisatieonderdelen die in een bepaald deel van de gemeente verschillende taken combineren (strategie/beleid/budgetten, uitvoering, advisering).

Hoofdvorm: Maatschappelijke binnengemeentelijke organisatie

L. Maatschappelijke binnengemeentelijke besluitvorming: functionele commissies op basis van de Gemeentewet met maatschappelijke instellingen en/of bedrijven als leden, die voor een bepaald deel van de gemeente besluiten neemt over strategie/beleid/budget.

M. Maatschappelijke binnengemeentelijke uitvoering: teams van medewerkers van maatschappelijke instellingen en/of bedrijven die in een bepaald deel van de gemeente taken uitvoeren, zoals wijk-/buurtteams.

N. Maatschappelijke binnengemeentelijke advisering: door de gemeente ingestelde commissies met (vertegenwoordigers van) maatschappelijke instellingen en/of bedrijven als leden, die adviseren over een bepaald deel van de gemeente.

O. Meervoudige maatschappelijke binnengemeentelijke organisatie: maatschappelijke instellingen en/of bedrijven die in een bepaald deel van de gemeente verschillende taken combineren (strategie/beleid/budgetten, uitvoering, advisering).

Hoofdvorm: binnengemeentelijke burgerparticipatie

P. Binnengemeentelijk participatief begroten: budgetten waarover inwoners van een bepaald deel van de gemeente mogen beslissen, zoals buurtbudgetten.

Q. Binnengemeentelijke burgerinitiatieven: een regeling voor inwoners om initiatieven te nemen voor de uitvoering van activiteiten in een bepaald deel van de gemeente.

R. Binnengemeentelijke burgeradvisering: vertegenwoordigingen van inwoners die de gemeente adviseren over zaken die een bepaald deel van de gemeente aangaan (zoals wijk-/dorpsraden, verenigingen plaatselijk belang) en die de gemeente ook als zodanig erkent.

S. Correctieve referenda: mogelijkheid voor raadplegende en/of raadgevende referenda in een bepaald deel van de gemeente: wijkreferenda.

T. Meervoudige binnengemeentelijke burgerparticipatie: inwoners die in een bepaald deel van de gemeente verschillende taken combineren (strategie/beleid/budgetten, uitvoering, advisering).

\section{Frequentie en vormen in de praktijk}

Met behulp van de hierboven gegeven typologie hebben wij geïnventariseerd welke vormen van binnengemeentelijke organisatie in Nederland voorkomen (zie 
Schaap \& Leenknegt, 2018 voor details). We merken hierbij op dat vormen zich in combinatie kunnen voordoen, maar dat we niet tot dat detailniveau gezocht hebben.

Het blijkt dat $80 \%$ van de gemeenten een vorm van binnengemeentelijke organisatie heeft. Dat lijkt niet erg af te wijken van de gegevens uit 2001, toen Berenschot vond dat $7 \%$ van de gemeenten een vorm van bestuurlijke decentralisatie kende, $24 \%$ vormen van ambtelijke deconcentratie en $77 \%$ tevens of uitsluitend andere vormen van (binnengemeentelijke) burgerparticipatie. In de gemeenten die geen vorm van binnengemeentelijke organisatie kennen, was de meest genoemde reden daarvoor dat de gemeente te klein is. Er zijn grote verschillen tussen de gemeenten als het gaat om de vormgeving van binnengemeentelijke organisatie. Vrijwel alle 20 verschillende vormen (zie kadertekst) komen in de deelnemende gemeenten voor, met als enige uitzondering vorm $\mathrm{D}$ - meervoudige politieke binnengemeentelijke organisatie. De meeste voorkomende (hoofd)vormen zijn (zie tabel 1):

- binnengemeentelijke burgerparticipatie: binnengemeentelijke burgeradvisering (vorm $\mathrm{R}, 83 \%$ van de gemeenten), binnengemeentelijke burgerinitiatieven (vorm Q; 62\% van de gemeenten), binnengemeentelijk participatief begroten (vorm P; $46 \%$ van de gemeenten);

- maatschappelijke binnengemeentelijke organisatie: maatschappelijke binnengemeentelijke uitvoering (vorm M; 50\% van de gemeenten);

- ambtelijke binnengemeentelijke organisatie: ambtelijke binnengemeentelijke uitvoering (vorm J; 41\% van de gemeenten) en meervoudige ambtelijke binnengemeentelijke organisatie (vorm K; 35\% van de gemeenten).

In 2001 (Berenschot, 2001) zag het er als volgt uit: bestuurlijke decentralisatie bestond in $7 \%$ van de gemeenten. In onze terminologie gaat het dan om politieke en maatschappelijke binnengemeentelijke organisatie (categorieën A tot en met D en $\mathrm{L}$ tot en met $\mathrm{O}$ ). In totaal geven 72 gemeenten aan dat zij die vormen hebben, ofwel twee derde van alle deelnemende gemeenten. Zelfs als we rekening houden met interpretatieverschillen en met de mogelijkheid dat gemeenten verschillende vormen combineren, is de conclusie gerechtvaardigd dat het voorkomen van deze vormen van binnengemeentelijke organisatie fors is toegenomen. Necker van Naem concludeerde in 2013 dat in meer dan 46\% van de gemeenten een dorpsen/of wijkraad aanwezig was. In ons onderzoek gaat het dan om vorm $\mathrm{R}$ en die komt in $83 \%$ van de gemeenten voor. Het lijkt erop dat het percentage gemeenten met ambtelijke deconcentratie niet is gewijzigd. Die vorm kwam volgens Berenschot (2001) in 24\% van de gemeenten voor, in 2017 in ongeveer een derde van de gemeenten (onze vormen I, J en K; het exacte percentage is niet uit te rekenen, doordat gemeenten verschillende vormen gecombineerd kunnen hebben).

Het initiatief tot binnengemeentelijke organisatie kwam in $72 \%$ van de gevallen van de gemeenten zelf (zie tabel 2). Binnengemeentelijke burgeradvisering is in de helft van de gevallen ontstaan op initiatief van anderen dan de gemeente (of is een gedeeld initiatief). 
Tabel 1 Zes meest voorkomende vormen van binnengemeentelijke organisatie

\begin{tabular}{l}
\hline $\mathbf{U}$ hebt aangegeven dat uw gemeente (één of meer) vor- $\mathbf{N}$ \\
men van binnengemeentelijke organisatie kent. Geeft u \\
a.u.b. aan welke vorm(en) dat zijn. ( $N=66$, meerdere ant- \\
woorden mogelijk)*
\end{tabular}

R. Vertegenwoordigingen van inwoners die de gemeente adviseren $55 \quad 83 \%$ over zaken die een bepaald deel van de gemeente aangaan (zoals wijk-/dorpsraden, verenigingen plaatselijk belang) en die de gemeente ook erkent.

Q. Een regeling voor inwoners om initiatieven te nemen voor de uitvoering van activiteiten in een bepaald deel van de gemeente.

M. Teams van medewerkers van maatschappelijke instellingen en/ of bedrijven die in een bepaald deel van de gemeente taken uitvoeren, zoals wijk-/buurtteams.

P. Budgetten waarover inwoners van een bepaald deel van de gemeente mogen beslissen, zoals buurtbudgetten.

J. Speciaal aangewezen ambtenaren/organisatieonderdelen die in een bepaald deel van de gemeente uitvoerende werkzaamheden verrichten.

K. Speciaal aangewezen ambtenaren/organisatieonderdelen die in 23 een bepaald deel van de gemeente verschillende taken combineren (strategie/beleid/budgetten, uitvoering, advisering).

* Deze tabel geldt alleen voor gemeenten die een vorm van binnengemeentelijke organisatie hebben.

\section{Tabel 2 Initiatief tot binnengemeentelijke organisatie}

\begin{tabular}{lll}
\hline $\begin{array}{l}\text { Wie nam het initiatief voor het creëren van deze vorm } \\
\text { van binnengemeentelijke organisatie? (resultaten voor in } \\
\text { totaal 20 vormen opgeteld) }\end{array}$ & $\mathbf{N}$ & $\%$ \\
\hline Gemeente & 215 & $72 \%$ \\
Anders, namelijk ... & 29 & $10 \%$ \\
Individuele burgers & 25 & $8 \%$ \\
Maatschappelijke organisaties & 18 & $6 \%$ \\
Onbekend & 10 & $3 \%$ \\
\hline
\end{tabular}

\section{Patronen}

Voor de meest genoemde organisatievormen is gezocht naar patronen, waaronder naar samenhang met inwoneraantal van de gemeente, het aantal kernen in de gemeente en de vraag of de gemeente het resultaat is van gemeentelijke herindeling. Alle verbanden zijn getoetst met behulp van een chi-kwadraattoets. Slechts drie verbanden bleken significant te zijn. Grotere gemeenten hebben vaker dan andere gemeenten ambtelijke binnengemeentelijke uitvoering (vorm J), meervoudige ambtelijke binnengemeentelijke organisatie (vorm $\mathrm{K}$ ) en maatschappelijke binnengemeentelijke uitvoering (vorm M).

Deze patronen zijn andere dan die in eerder onderzoek gevonden werden. In 2001 concludeerde Berenschot dat binnengemeentelijke decentralisatie (in onze 
Tabel 3 Juridische vorm binnengemeentelijke organisatie

\begin{tabular}{lll}
\hline $\begin{array}{l}\text { Welke juridische grondslag heeft deze vorm van binnen- } \\
\text { gemeentelijke organisatie in uw gemeente? (resultaten } \\
\text { voor in totaal 20 vormen opgeteld) }\end{array}$ & N & \\
\hline Bevoegdheden op basis van de Gemeentewet & 116 & $39 \%$ \\
Geen/onbekend & 110 & $37 \%$ \\
Andere publieke wetgeving & 36 & $12 \%$ \\
Een combinatie van publiek- en privaatrecht & 24 & $8 \%$ \\
Privaatrecht & $\mathrm{II}$ & $4 \%$ \\
\hline
\end{tabular}

termen: de hoofdvorm politieke binnengemeentelijke organisatie) sterker bij gemeenten met meer dan 100.000 inwoners voorkwam dan bij andere inwonersaantallen. Daarnaast werden toen verbanden gevonden tussen het invoeren van vormen van binnengemeentelijke organisatie en het heringedeeld zijn van gemeenten. Ook Necker van Naem (2013) trof een (significant?) verband aan: in herindelingsgemeenten was meer en vaker sprake van het bestaan van dorps- en wijkraden (binnengemeentelijke burgeradvisering; vorm $\mathrm{R}$ ).

\section{Het juridisch kader}

Het tweede deel van de vraagstelling die in dit artikel centraal staat, betreft mogelijke wettelijke belemmeringen voor de vormgeving van binnengemeentelijke organisatie. De juridische grondslag voor binnengemeentelijke organisatie is divers (tabel 3).

In deze paragraaf besteden we aandacht aan het juridisch kader voor binnengemeentelijke organisatie. Met name de Grondwet, de Gemeentewet en de Algemene wet bestuursrecht bevatten dwingende bepalingen ten aanzien van de inrichting en werking van het gemeentebestuur. In deze paragraaf bespreken wij op basis van de genoemde regelingen de wettelijke voorzieningen en mogelijkheden voor binnengemeentelijke organisatie. Medebewindswetgeving betreft alleen functionele vormen van bestuur binnen gemeenten en daar gaat deze bijdrage niet over. Wel kijken we ook naar privaatrechtelijke mogelijkheden.

\subsection{De Grondwet}

Het constitutionele kader voor binnengemeentelijke organisatie is in hoofdzaak neergelegd in de artikelen 125 en 127-128 van de Grondwet. In onderlinge samenhang geven deze bepalingen aan welke ruimte er bestaat voor binnenge- 
meentelijke organisatie en voor de toekenning van regelgevende en bestuurlijke bevoegdheden aan gemeentelijke organen. ${ }^{3}$

In artikel 127 Grondwet is vastgelegd dat de gemeenteraad in beginsel de gemeentelijke verordeningen vaststelt. De bepaling laat wel ruimte voor de wetgever of, indien de wetgever dat mogelijk maakt, voor de gemeenteraad om verordenende bevoegdheid toe te kennen aan andere gemeentelijke organen. In artikel 128 Grondwet is bepaald onder welke voorwaarden autonome bevoegdheden kunnen worden toegekend aan andere organen dan de hoofdorganen genoemd in artikel 125 Grondwet. Voor medebewindsbevoegdheden geldt artikel 128 Grondwet niet: de wetgever kan dus in medebewindswetgeving - regeling of bestuur, gevorderd bij of krachtens andere wetten dan de Gemeentewet; zie artikel 108, tweede lid, Gemeentewet - desgewenst bepalen dat andere gemeentelijke organen dan de drie in artikel 125 Grondwet genoemde, bevoegdheden verkrijgen. Hij kan de bevoegdheid daartoe ook aan andere (rijks- of provinciale) organen overdragen (zie ook Van der Woude, 2019). In beginsel bepaalt de betreffende medebewindswet steeds of een aan de raad toegekende bevoegdheid mag worden overgedragen. Niet in alle gevallen zal overigens volstrekt duidelijk zijn wat de bedoeling is van de betreffende medebewindswet; het wordt dan een interpretatiekwestie waarover uiteindelijk de bestuursrechter beslist (Konijnenbelt, 2013).

Wat betreft de wijze van samenstelling van gemeentelijke organen waarborgt artikel 4 Grondwet in algemene zin voor alle Nederlanders het recht om gelijkelijk de leden van de algemeen vertegenwoordigende organen te kiezen en daarin verkozen te worden. ${ }^{4}$ Onder de in artikel 4 Grondwet bedoelde 'algemeen vertegenwoordigende organen' vallen in elk geval de gemeenteraden. Bestuurscommissies en andere binnengemeentelijke organen zullen gewoonlijk niet als algemeen vertegenwoordigende organen zijn aan te merken. Dat houdt in dat verkiezing van de leden daarvan niet grondwettelijk is vereist; wel staat het de gemeenteraad vrij zelf tot rechtstreekse verkiezing van de leden van een ander gemeentelijk orgaan te besluiten.

\subsection{De Gemeentewet}

\section{- Bevoegdheidsoverdracht aan gemeentelijke commissies}

In de artikelen 82-86 van de Gemeentewet wordt de mogelijkheid geopend tot het instellen van commissies. Deze bepalingen geven algemene regels over de samenstelling van commissies, het voorzitterschap, de verantwoordingsplichten en de openbaarheid van vergaderingen. Over de bevoegdheden van de verschillende com-

3 Deze bepalingen in de Grondwet betreffen overigens steeds de organisatie en bevoegdheden van zowel het provincie- als het gemeentebestuur; in het navolgende worden slechts de gemeentelijke organen en hun bevoegdheden genoemd.

4 Artikel 129 Grondwet vormt een nadere concretisering van artikel 4 voor de verkiezingen voor (onder meer) de gemeenteraad: de bepaling schrijft rechtstreekse verkiezingen van de leden voor en koppelt de eisen voor actief en passief kiesrecht voor de gemeenteraden aan eisen die gelden voor de verkiezing van de leden van de Tweede Kamer. Zie Van der Woude, 2019. 
missies worden regels gesteld in de artikelen 156 (bestuurscommissies van de raad), 165 (bestuurscommissies van het college) en 178 (bestuurscommissies van de burgemeester) van de Gemeentewet. Het uitgangspunt is daarbij steeds dat overdracht van bevoegdheden aan commissies mogelijk is, tenzij de aard van de bevoegdheid zich daartegen verzet. ${ }^{5}$

De betekenis van die laatste zinsnede is niet exact afgebakend. Er zijn enkele aanknopingspunten te vinden in de parlementaire geschiedenis van de Gemeentewet en in de rechtspraak. Daaruit blijkt bijvoorbeeld dat bevoegdheden die betrekking hebben op de verhouding tussen de raad en het college van burgemeester en wethouders zich niet voor delegatie lenen. ${ }^{6}$ Verder is delegatie van medebewindsbevoegdheden uitgesloten wanneer de medebewindswet die de bevoegdheid toekent, zich daartegen verzet. ${ }^{7}$

Daarnaast worden in de Gemeentewet voor de raad (artikel 156, tweede lid) en de burgemeester $^{8}$ enkele concrete bevoegdheden genoemd die niet overdraagbaar zijn. In algemene zin geldt ten slotte dat delegatie aan ondergeschikten niet mogelijk is (art. 10:14 Awb). Aangezien ambtenaren en ambtelijk samengestelde commissies ondergeschikt zijn aan het gemeentebestuur, is delegatie van bevoegdheden daaraan niet toegestaan. Mandatering van de uitoefening van die bevoegdheden is wel mogelijk. Het verschil tussen beide vormen van bevoegdheidstoedeling is dat in het geval van mandaat de verantwoordelijkheid voor de uitoefening van de bevoegdheid niet wordt overgedragen; de mandaatgever blijft verantwoordelijk voor het in zijn naam gevoerde bestuur. Delegatie van bevoegdheden impliceert overdracht van de verantwoordelijkheid voor de uitoefening van de overgedragen bevoegdheid (Michiels, 2016: 88-89).

Ook ten aanzien van mandaat bepaalt de wet dat de aard van een bevoegdheid zich tegen mandatering kan verzetten (artikel 10:3, eerste lid, Awb). Dat zou met name gelden voor de openbare ordebevoegdheden van de burgemeester (hoofdstuk XI van de Gemeentewet); het gaat om verstrekkende bevoegdheden waarmee ingrijpende beslissingen worden genomen, die in veel gevallen raken aan de uit-

5 De zinsnede werd toegevoegd aan de betreffende bepalingen in de Gemeentewet bij Wet van 20 december 2001, houdende wijziging van de Gemeentewet, de Provinciewet en de Waterschapswet inzake verbetering van de afstemming op de Algemene wet bestuursrecht en enige andere verbeteringen, Stb. 2002, 13.

6 Zie Kamerstukken II 2000/01, 27 547, A, p. 3; Kamerstukken I 1990/91, 19 403, 64b, p. 4-5. Zie ook T.D. Cammelbeeck \& R. Nehmelman (red.), Tekst \& Commentaar Gemeentewet en Provinciewet, Deventer: 2017, commentaar bij artikel 156 Gemeentewet.

7 ABRvS 15 februari 1999, Gst. 1999-7098, 2. Een concreet voorbeeld is Rechtbank Den Haag 24 februari 2010 AWB-09_3755, ECLI:NL:RBSGR:2010:BL6114, waarin de aard van de bevoegdheid toegekend in artikel 15 van de WMO geacht wordt zich te verzetten tegen delegatie aan een commissie.

8 De burgemeester kan de bevoegdheden tot aanwijzing van veiligheidsrisicogebieden (art. 151b Gemeentewet), tot bestuurlijke ophouding (art. 154a Gemeentewet) en het gebruik van de bevoegdheden in het kader van de handhaving van de openbare orde, neergelegd in de artikelen 172-176a Gemeentewet, niet overdragen (art. 178, tweede lid, Gemeentewet). 
oefening van grondrechten. ${ }^{9}$ Verder wordt aangenomen dat de bevoegdheid tot het vaststellen van algemeen verbindende voorschriften in beginsel niet kan worden gemandateerd (Michiels, 2016: 89).

\section{- Territoriale commissies en de inrichting van deelgemeenten}

In 2013 werd de Gemeentewet gewijzigd met het oog op de afschaffing van de deelgemeenten. ${ }^{10}$ Deze voorziening in de Gemeentewet, waarvan tot dat moment alleen Amsterdam en Rotterdam gebruik hadden gemaakt, bestond in feite uit de mogelijkheid om territoriale commissies in te richten met een breed pakket aan taken en bijbehorende bevoegdheden, waaronder verordenende bevoegdheden, met een dwingende regeling aangaande de bestuurlijke inrichting daarvan. De bedoeling van de opheffing ervan was het aantal bestuurslagen waarmee de burger te maken had te verkleinen, in een poging de 'bestuurlijke drukte' te verminderen. ${ }^{11}$

Ondanks deze wijziging staat het gemeenteraden nog altijd vrij territoriale commissies in te richten. Deze bestuurscommissies hebben in beginsel een lichtere taak dan de afgeschafte deelgemeenten, ${ }^{12}$ maar kunnen een aanzienlijk pakket aan taken hebben, inclusief verordenende bevoegdheden. Daarbij gelden de beperkingen die artikel 156, tweede lid, Gemeentewet vermeldt. Onder meer de bevoegdheid tot het vaststellen van verordeningen die met sancties of bestuursdwang worden gehandhaafd, kan niet worden overgedragen; daarvoor blijft alleen de gemeenteraad bevoegd. Wel is, krachtens het derde lid van artikel 156 Gemeentewet, overdracht van de bevoegdheid tot nadere uitwerking van dergelijke verordeningen aan commissies mogelijk.

\section{- De inrichting van de gemeentelijke uitvoeringsorganisatie}

Verschillende veelgebruikte vormen van binnengemeentelijke organisatie komen feitelijk tot uitdrukking in de vormgeving van de gemeentelijke uitvoeringsorganisatie. In juridische zin gaat het dan om deconcentratie: het spreiden van uitvoeringstaken binnen de gemeentelijke ambtelijke hiërarchie. Zo kunnen onderdelen van de ambtelijke organisatie, of daartoe aangewezen ambtenaren, specifieke taken krijgen die zij uitoefenen voor bepaalde delen van de gemeente. De Gemeentewet is zeer beknopt over de inrichting van de gemeentelijke uitvoeringsorganisatie. De inrichting van de ambtelijke dienst behoort tot de bevoegdheden van het college (art. 160, eerste lid, onder c en d, Gemeentewet), met uitzondering van de organisatie van de griffie. De Gemeentewet laat verder aan het college een ruime vrijheid om de uitvoeringsorganisatie in te richten om de gemeentelijke taken uit te voeren.

9 Kamerstukken II 1993/94, 23 700, nr. 3, p. 170; daarin wordt verwezen naar ARRvS 17 december 1991, AB 1992, 55, en Hof Amsterdam 4 mei 1990, AB 1991, 30.

10 Stb. 2013, 76; de wijziging trad in werking op 19 maart 2014. Voor de parlementaire behandeling ervan zie Kamerstukken 33017.

11 Kamerstukken II 2011/12, 33 017, nr. 3, p. 1 e.v..

12 Kamerstukken II 2011/12, 33 017, nr. 3, p. 2 en nr. 6, p. 2 e.v.; zie ook Kamerstukken I 2013/14, 33 017, nr. F (brief inzake overdracht van bevoegdheden aan bestuurscommissies (T01664)). 
Ook hier geldt overigens dat delegatie van bevoegdheden aan ondergeschikten - zoals ambtenaren - niet mogelijk is. Mandatering van de uitoefening van bestuursbevoegdheden aan ambtenaren is wel mogelijk.

\subsection{Privaatrechtelijke instrumenten}

Het gemeentebestuur kan ook privaatrechtelijke middelen hanteren om beleidsdoelstellingen te realiseren, voor zover daarmee niet de publiekrechtelijke regeling wordt doorkruist. ${ }^{13}$ Ook hiervoor biedt de Gemeentewet de wettelijke basis: volgens artikel 160, eerste lid, onder e, Gemeentewet is het college bevoegd om te besluiten tot privaatrechtelijke rechtshandelingen van de gemeente. Hiermee kan gemeentelijk beleid worden vormgegeven met behulp van privaatrechtelijke constructies - stichtingen, maar ook met andere rechtspersonen en organisatievormen. ${ }^{14}$ Niet alle gemeentelijke taken lenen zich echter voor uitoefening volledig buiten het publieke domein. Commerciële of andere 'eigen' belangen van private organisaties kunnen strijdig zijn met het publieke belang dat het gemeentebestuur geacht wordt te dienen. Zo besliste de Centrale Raad van Beroep dat een gemeentebestuur de kerntaken in verband met de uitvoering van de Wet werk en bijstand niet mocht uitbesteden aan een commercieel bedrijf, omdat uit de wet blijkt dat de wetgever de bedoeling heeft beslissingen omtrent bijstandverlening in het publieke domein te houden. ${ }^{15}$

Uit de enquête onder de gemeentesecretarissen (Schaap \& Leenknegt, 2018) bleek, dat $51 \%$ van de huidige binnengemeentelijke organisatie een publiekrechtelijke grondslag heeft.

\subsection{Juridische belemmeringen voor binnengemeentelijke organisatievormen}

Het geschetste wettelijke kader begrenst de mogelijkheden voor binnengemeentelijke organisatievormen vooral met algemene noties: delegatie van bevoegdheden aan ondergeschikten is niet mogelijk; verordenende bevoegdheid kan niet worden gemandateerd; de bevoegdheid tot het vaststellen van verordeningen door straffen te handhaven is niet overdraagbaar aan commissies; de aard van een bevoegdheid kan zich verzetten tegen overdracht daarvan. Een relevante vraag is of en in hoeverre dit algemene wettelijke kader belemmerend werkt voor het inrichten van uiteenlopende vormen van binnengemeentelijke organisatie.

In de praktijk blijken er soms inderdaad concrete juridische belemmeringen te bestaan. Deze kunnen zich al voordoen op het moment dat er voorbereidingen worden getroffen om bepaalde vormen van binnengemeentelijke organisatie in te richten. Concrete ideeën en voorstellen blijken zich dan niet altijd met de

14 Dwingende bepalingen over de inrichting en het functioneren van rechtspersonen zijn neergelegd in Boek 2 van het Burgerlijk Wetboek.

15 Centrale Raad van Beroep 16 september 2014, zaaknummer 11-6506 WWB, ECLI:NL:CRVB: 2014:2947. 
wettelijke kaders te verdragen. ${ }^{16}$ Een voorbeeld is het idee om een bestemmingsplan te laten vaststellen in delen, door afzonderlijke gebiedscommissies, waarna de raad die delen slechts zou samenvoegen en formeel als één bestemmingsplan voor de gehele gemeente zou vaststellen. Gezien artikel 3.1 van de Wet ruimtelijke ordening komt de bevoegdheid tot vaststelling van een bestemmingsplan echter uitsluitend toe aan de gemeenteraad. De vaststelling van een bestemmingsplan is daarmee een bevoegdheid die naar haar aard niet kan worden overgedragen; de medebewindswet (de Wet ruimtelijke ordening) maakt daartoe uitsluitend de raad bevoegd.

Blijkens ons onderzoek (Schaap \& Leenknegt, 2018) doen juridische belemmeringen zich bij het vormgeven van binnengemeentelijke organisatie soms wel voor, maar welke dat concreet zijn, is niet duidelijk geworden uit de antwoorden op onze enquêtevragen.

\section{Effecten op burgerparticipatie}

In deze paragraaf bespreken we de effecten van binnengemeentelijke organisatie op burgerparticipatie die gedocumenteerd zijn in de literatuur dan wel blijken uit de enquête onder de gemeentesecretarissen. We besteden aandacht aan drie van de vijf hoofdtypen binnengemeentelijke organisatie (zie de kadertekst), namelijk politieke en ambtelijke binnengemeentelijke organisatie, en binnengemeentelijke burgerparticipatie (over de effecten van bestuurlijke en maatschappelijke binnengemeentelijke organisatie hebben we geen betrouwbare literatuur kunnen vinden).

\section{Politieke binnengemeentelijke organisatie}

Uit wat oudere evaluaties van Rotterdamse deelgemeenten en Amsterdamse stadsdelen (Hakvoort, 1980; WRR, 1998) blijkt dat politieke binnengemeentelijke organisatie geen effect heeft op de participatie van burgers in het publieke domein. Recente evaluaties van hun opvolgers - 'gebiedscommissies' in Rotterdam en 'bestuurscommissies' in Amsterdam ${ }^{17}$ - geven een weinig positiever beeld te zien. In Rotterdam is het streven van de gemeente naar het terugdringen van de dominantie van politieke partijen niet gelukt (Loorbach e.a., 2016: 46) en wordt het stimuleren van de burgerparticipatie in sommige gebieden enigszins belemmerd door 'partijpolitiek' en interne kwesties (Loorbach e.a., 2016: 101). Concluderend stellen de onderzoekers - evenals twee derde van de ondervraagde Rotterdammers en $80 \%$ van de gebiedscommissieleden - dat het bestuursmodel niet dichter bij de burger is gekomen. De uitkomsten van de evaluatie van het nieuwe Amsterdamse model met bestuurscommissies (Brenninkmeijer e.a., 2016) wijken amper af van die uit Rotterdam. Daar is ook nog eens '(...) eerder en vaker strijd dan coöperatie. Het wij-zij denken is in Amsterdam sterk aanwezig en het

16 Dergelijke belemmeringen zijn weinig gedocumenteerd, aangezien zij de besluitvormende fase vaak niet bereiken.

17 Beide vormen zijn geïntroduceerd nadat de deelgemeenten uit de Gemeentewet geschrapt waren. 
onderling wantrouwen is groot. Dat uit zich niet zozeer tussen individuen, maar vooral tussen organisatieonderdelen, zowel ambtelijk, bestuurlijk als politiek' (Brenninkmeijer e.a., 2016: 21).

\section{Ambtelijke binnengemeentelijke organisatie}

Er is erg weinig literatuur gevonden over de effecten van ambtelijke binnengemeentelijke organisatie op burgerparticipatie. In een afstudeerscriptie (Bihari, 2008) met daarin een vergelijking tussen de effecten van ambtelijke binnengemeentelijke organisatie (in Enschede-Zuid) en politieke binnengemeentelijke organisatie (in de Rotterdamse deelgemeente Hoogvliet) wordt geconcludeerd dat de gesignaleerde verschillen tussen de rollen die burgers in beide wijken spelen niet verklaard kunnen worden uit de verschillen in vormgeving van de binnengemeentelijke organisatie.

Een positiever resultaat laat een evaluatie van een andere vorm van ambtelijke binnengemeentelijke organisatie zien, namelijk wijkcoaches in de (sociaal zwakke) wijk Velve-Lindehof in Enschede (Klok e.a., 2012). Een van de doelstellingen was om de sociale vaardigheden van de bewoners te vergroten en hen te laten stijgen op de participatieladder. Er was op beide vlakken een positieve ontwikkeling zichtbaar, en dan vooral bij de inwoners die voorheen het laagst scoorden (bij ongeveer een kwart van de inwoners waren er geen verbeteringen). Langere ondersteuning door de wijkcoaches leidde tot een beter resultaat.

\section{Binnengemeentelijke burgerparticipatie}

Omdat het ondoenlijk is om de ontelbare voorbeelden van burgerparticipatie die - soms - binnengemeentelijk uitgevoerd worden in kaart te brengen en de effecten daarvan te evalueren, kijken we hier uitsluitend naar die vormen van binnengemeentelijke burgerparticipatie die een vaste organisatie kennen, zoals wijk- en dorpsraden. Lammerts en Verwijs (2009: 18) constateerden dat sommige groepen wijkbewoners - jongeren, allochtonen - ondervertegenwoordigd zijn en dat wijkraden veel verloop in deelnemers kennen. Vier jaar later luidde de conclusie van Necker van Naem (2013) dat vaak slechts een kleine groep inwoners deelneemt (en soms te dominant is) en dat de benadering dikwijls te zeer top-down is: de wensen en voornemens van de gemeente staan centraal en niet het stimuleren van initiatieven van inwoners zelf. Reussings relativerende conclusie lijkt terecht: '(...) mogen er geen overdreven positieve resultaten worden verwacht van binnengemeentelijk bestuur. Zeker als de inbreng van territoriale bestuurscommissies beperkt blijft tot advisering is (...) de daadwerkelijke invloed van burgers op de besluitvorming gering' (Reussing, 2013).

\section{Literatuurstudie versus enquêteresultaten}

De effecten van de meeste vormen van binnengemeentelijke organisatie op de burgerparticipatie zijn dus gering of afwezig, als we op de literatuur afgaan. Eigenlijk treffen we alleen een positief effect aan bij ambtelijke binnengemeentelijke organisatie, in de vorm van wijkcoaches in een sociaal zwakke wijk. 
Interessant is vervolgens dat $95 \%$ van de gemeentesecretarissen het 'versterken van de burgerparticipatie' als reden noemt voor het binnengemeentelijk organiseren (Schaap \& Leenknegt, 2018). Zij zijn ook veel positiever over de effecten van binnengemeentelijke organisatie op de burgerparticipatie. Een grote meerderheid van hen is het erover eens ('eens' en 'helemaal eens') dat binnengemeentelijke organisatie vergrotend/versterkend werkt op burgerparticipatie (92\%) en de kwaliteit van de lokale democratie (70\%). Deze antwoorden hebben we helaas niet kunnen differentiëren naar de afzonderlijke vormen van binnengemeentelijke organisatie.

Een verklaring voor het verschil tussen hetgeen we uit de literatuur leren en de waarnemingen van de gemeentesecretarissen is niet meteen voorhanden. Er kunnen daadwerkelijk verbeteringen zijn opgetreden de afgelopen jaren; het kan ook zijn dat de gemeentesecretarissen een te rooskleurig beeld hebben (zo stelt 95\% van de respondenten dat 'het versterken van de burgerparticipatie' een reden is voor het overgaan tot binnengemeentelijke organisatie).

\section{Effecten op bestuurskracht}

In deze paragraaf bespreken we de effecten van binnengemeentelijke organisatie op de bestuurskracht van de gemeenten. Ook hier maken we gebruik van de literatuur en de enquête onder de gemeentesecretarissen.

\section{Politieke binnengemeentelijke organisatie}

De vroegere Rotterdamse deelgemeenten bleken niet effectiever te zijn dan gebieden zonder deelgemeente (Hakvoort, 1980). In Amsterdam was wel sprake van een toename van de effectiviteit (WRR, 1998). Het meten van de effecten van het nieuwe Rotterdamse bestuursmodel met gebiedscommissies blijkt lastig te zijn (Loorbach e.a., 2016). De gebiedscommissieleden ervaren weinig impact van hun adviezen. En er is 'een toegenomen conflict en kloof waar te nemen tussen "de stad" en "het gebied" wat leidt tot concurrentie en weinig synergie. Ook tussen gebiedscommissies en ambtenaren heerst in een aantal gebieden nog een flink wantrouwen' (Loorbach e.a., 2016: 5). In Amsterdam blijkt dit eveneens het geval te zijn. 'Bestuurscommissies voelen zich niet serieus genomen door de centrale stad (zowel bestuurlijk als ambtelijk) (...). Adviezen worden te laat gevraagd en vervolgens niet serieus genomen en er vindt onvoldoende terugkoppeling plaats' (Brenninkmeijer e.a., 2016: 22).

\section{Bestuurlijke binnengemeentelijke organisatie}

De WRR (2004) heeft aandacht besteed aan het wijkgerichte werken in Utrecht (een combinatie van wijkraadscommissie en wijkwethouders: bestuurlijke binnengemeentelijke organisatie), ambtelijke wijkbureaus (ambtelijke binnengemeentelijke organisatie), en mogelijkheden voor burgerinitiatieven en wijkraden (binnengemeentelijke burgeradvisering). De deelnemers aan de wijkraden waren van mening dat de wijkraadscommissies niet goed functioneerden. 


\section{Ambtelijke binnengemeentelijke organisatie}

In het eerder hiervoor aangehaalde rapport van de WRR (2004) staat ook een constatering over de ambtelijke binnengemeentelijke organisatie in Utrecht. De deelnemers aan de wijkraden waren vooral ontevreden over de manier waarop met ongevraagde adviezen werd omgegaan: die vonden hun weg niet in de ambtelijke organisatie.

\section{Maatschappelijke binnengemeentelijke organisatie}

Een van de weinige gedocumenteerde vormen van jaren geleden treffen we in Noord-Limburg aan. Daar is maatschappelijke samenwerking ontstaan tussen, in eerste instantie, een zorgcentrum in Panningen en de wooncorporatie (WRR, 2004). Daaruit kwam een werkgroep voort met vertegenwoordigers van de wooncorporatie, zorgaanbieder, welzijnsstichting en de gemeente Helden. Die werkgroep leverde een visienota op met de intentie dat die - onder regie van de gemeente - uitgevoerd zou worden. Vervolgens is er een projectorganisatie in het leven geroepen met diverse organen, waarin elke betrokken organisatie op elk niveau zitting had. De gemeente heeft ambtelijke ondersteuning geregeld, die aan elk overleg deelneemt. De fysieke plannen zijn deels gerealiseerd, de zorgkant van de plannen is minder uit de verf gekomen. Dat rechtvaardigt de conclusie dat deze maatschappelijke binnengemeentelijke organisatie enigszins heeft bijgedragen aan de bestuurskracht van de gemeente.

Deze vorm van binnengemeentelijke organisatie is de laatste jaren nogal in opkomst, veelal in het kader van de gedecentraliseerde zorgtaken, bijvoorbeeld onder de noemer 'wijkteams'. Sommige gemeenten hebben hier een proef mee gedaan en die proeven - of 'pilots ' - laten evalueren of zelf geëvalueerd (een overzicht biedt Movisie, 2014). Beschikbare studies zijn veelal eerder te beschouwen als voorlopige evaluaties dan dat zij definitieve conclusies bevatten. Bovendien ontbreekt het nogal eens aan vergelijkingen met de situatie voor de pilots. Zo blijkt uit de evaluatie van de Tielse pilot met wijkteams jeugd (Gilsing \& Hermens, 2016) weliswaar dat het de teams redelijk goed lukte om integrale ondersteuning te bieden en casusregie te voeren (en dat andere verwachte effecten amper uitkwamen), maar kan niet worden geconcludeerd dat het werken met wijkteams beter is. In Rotterdam blijkt dat het werken met wijkteams efficiënter is dan zonder: betere resultaten voor cliënten tegen - veelal - lagere kosten (Ecorys, 2016). Andere studies laten vooral zien dat er nog veel te verbeteren valt in het functioneren van de wijkteams (Movisie, 2018; De Koster, 2018).

Eenduidige conclusies zijn uit de diverse studies en casus niet te trekken. Er zijn voorbeelden van een relatief succesvolle aanpak en ook van benaderingen die nog veel verbetering vergen.

\section{Binnengemeentelijke burgerparticipatie}

Het hiervoor aangehaalde rapport van de WRR (2004) bevat enkele cases die ons iets vertellen over effecten op de bestuurskracht, voor zover destijds bekend; we bespreken er twee. In de Deventer wijkaanpak namen burgers besluiten over een 
budget. Uit een enquête bleek dat inwoners de indruk hadden dat de wijken met de wijkaanpak er beter voorstonden dan andere wijken. Dat kan wijzen op een licht positief effect op de bestuurskracht. De gemeente Zaanstad heeft op het gebied van wijkgericht werken en wijkbudgetten aantoonbaar resultaat geboekt: het aantal respondenten dat vond dat de gemeente weinig aandacht voor problemen in hun buurt had, was tussen 1998 en 2000 stevig gedaald (16 procentpunt, en in 2002 echter weer gestegen met 6 procentpunt). Ook hier kunnen we spreken van een positief effect op de bestuurskracht.

Over effecten van dorps- en wijkraden op de bestuurskracht van de gemeente is niet veel bekend. In het rapport van Necker van Naem (2013) is wel iets te lezen over de invloed van dergelijke raden op beleid en doorwerking. Bestuurders en ambtenaren zijn tamelijk positief over de doorwerking van adviezen van de dorps- en wijkraden. De bestuurders van die raden denken daar echter anders over: zij voelen zich niet vroegtijdig betrokken, lopen tegen vaste sectorale beleidskaders aan, en ze horen weinig terug van uitgebrachte adviezen.

Een aantal gemeenten heeft geëxperimenteerd met buurtbudgetten en heeft die experimenten ook geëvalueerd (bijvoorbeeld Utrecht, 2016 en 2018). Op de resultaten in één gemeente gaan we in: de gemeente Dordrecht. We beschrijven hier twee experimenten (Boluijt e.a., 2012). De gemeente heeft in de jaren voor 2010 in twee wijken participatief begroten ingezet (in Nieuw Krispijn werd geld vrijgemaakt voor extra activiteiten, in Stadspolders kregen bewoners de ruimte om bestaande budgetten te herverdelen). In beide gevallen bleek dat de bewoners niet enthousiast waren en dat zij het gevoel hadden dat zij de gemeente moesten vertellen wat de gemeente moest doen, terwijl dat wel al bekend zou moeten zijn. Wel leek het erop dat het vertrouwen in de gemeente vergroot is (Boluijt e.a., 2012: 42). Een belangrijke factor was dat de wederzijdse verwachtingen nogal verschillend waren: de bewoners wilden aanpak van concrete vraagstukken, de gemeente zocht actief burgerschap. De gemeente zelf is in haar evaluatie (2011) positiever dan de wijkbewoners, zij het dat zij vooral neveneffecten van het participatief begroten noemt: het op grote schaal geactiveerd zijn van bewoners (met de kanttekening dat de meeste geactiveerden niet intensief betrokken waren) en de ervaring die de gemeente heeft opgedaan met het benaderen van verschillende soorten burgers (in termen van burgerschapsstijlen). Een direct effect van het werken met buurtbudgetten dat de gemeente noemt, is dat buurtbewoners werkelijk meer beslissingsbevoegdheid hebben gekregen over een deel van de begroting.

Eén vorm van burgerparticipatie zonder vaste organisatievorm willen we toch noemen: het 'Buurt Bestuurt'-project in de buurt Hillesluis in Rotterdam (Schuilenburg, 2017). Daarmee werd beoogd een deel van de besluitvorming over de prioriteiten in de aanpak van onveiligheid in de wijk aan de inwoners over te dragen. $\mathrm{Zij}$ konden een top-drie van problemen doorgeven, waarna politie en gemeente die problemen moesten aanpakken, in samenspraak met de inwoners. De inwoners voelden zich echter te weinig geïnformeerd (Schuilenburg, 2017), waardoor zij minder goed hun top-drie verwoordden en politie en gemeente minder 
goed op de hoogte waren van de prioriteiten van de inwoners. Anders gezegd: er is weinig effect op de bestuurskracht doordat gemeente en politie de inwoners maar matig informeren.

\section{Literatuurstudie versus enquêteresultaten}

De effecten van de meeste vormen van binnengemeentelijke organisatie op de bestuurskracht van de burgerparticipatie blijken niet groot te zijn, althans: voor zover bekend in de literatuur. We zien wel enige effecten bij maatschappelijke binnengemeentelijke organisatie en bij binnengemeentelijke burgerparticipatie.

Ook hier signaleren we dat de geënquêteerde gemeentesecretarissen positiever lijken te zijn dan wat we op basis van de literatuur kunnen concluderen. Zij zijn positief ('eens' en 'helemaal eens') over de effecten van binnengemeentelijke organisatie op de responsiviteit van het gemeentebestuur (96\%), kans op betere outcomes (89\%), kennis van het gemeentebestuur over zijn maatschappelijke opgaven $(87 \%)$ en de veerkracht - het vermogen tot veranderen - van het gemeentebestuur (67\%). Maar er zijn ook minder eenduidige resultaten. Zo verschillen de respondenten van mening over het effect van binnengemeentelijke organisatie op het vermogen van het gemeentebestuur om beleid te maken (50\% '(helemaal) eens', $32 \%$ 'niet eens/niet oneens' en $18 \%$ 'oneens'), de effectiviteit van het gemeentebestuur (55\% '(helemaal) eens', 33\% 'niet eens/niet oneens' en $12 \%$ 'oneens'), bestuurskracht van het gemeentebestuur (48\% '(helemaal) eens', 37\% 'niet eens/niet oneens' en $15 \%$ '(helemaal) oneens') en de efficiëntie van het gemeentebestuur (32\% 'eens', 47\% 'niet eens/niet oneens' en 22\% '(helemaal) oneens').

Evenmin als bij de effecten op burgerparticipatie kunnen we hier een verklaring geven voor de spanning tussen hetgeen we uit de literatuur leren en de waarnemingen van de gemeentesecretarissen. Er kunnen daadwerkelijk verbeteringen zijn opgetreden de afgelopen jaren; het kan ook zijn dat de gemeentesecretarissen een te rooskleurig beeld hebben (zo stelt $95 \%$ van de respondenten dat 'versterken van de burgerparticipatie' een reden is voor het overgaan tot binnengemeentelijke organisatie).

\section{Conclusies}

Wat is de stand van zaken met betrekking tot binnengemeentelijke organisatie in Nederland, en in hoeverre belemmeren wettelijke bepalingen het zoeken naar adequate binnengemeentelijke oplossingen voor schaalvraagstukken? Zo luidde de hoofdvraag in het onderzoek dat de basis vormt van dit artikel.

In een nieuwe - en rijkere - indeling van vormen van binnengemeentelijke organisatie hebben we vijf hoofdtypen onderscheiden: politieke, bestuurlijke, ambtelijke en maatschappelijke binnengemeentelijke organisatie en binnengemeentelijke burgerparticipatie. Per hoofdtype hebben we een verfijning gemaakt naar aspecten van beleidsvorming: (mee)beslissen, uitvoeren, adviseren en combina- 
ties daarvan. In de praktijk komen drie hoofdvormen het meest frequent voor. In de eerste plaats binnengemeentelijke burgerparticipatie; meer specifiek gaat het dan om vertegenwoordigingen van inwoners die de gemeente adviseren over zaken die een bepaald deel van de gemeente aangaan, een regeling voor inwoners om initiatieven te nemen voor uitvoering van activiteiten in een bepaald deel van de gemeente, en om budgetten waarover inwoners van een bepaald deel van de gemeente mogen beslissen. In de tweede plaats komt maatschappelijke binnengemeentelijke organisatie vaak voor en dan gaat het in het bijzonder om teams van medewerkers van maatschappelijke instellingen en/of bedrijven die in een bepaald deel van de gemeente taken uitvoeren. En de derde veelvuldig voorkomende hoofdvorm is ambtelijke binnengemeentelijke organisatie; hier gaat het dan vooral om speciaal aangewezen ambtenaren dan wel organisatieonderdelen die in een bepaald deel van de gemeente uitvoerende werkzaamheden verrichten en om speciaal aangewezen ambtenaren/organisatieonderdelen die in een bepaald deel van de gemeente verschillende taken combineren. Politieke en bestuurlijke binnengemeentelijke organisatie komen veel minder vaak voor, en dat geldt ook voor vormen waarbij sprake is van besluitvorming op binnengemeentelijk niveau. De juridische ruimte daarvoor is weliswaar beperkt, maar die is er wel. Blijkbaar ontbreekt de politieke wens om daartoe over te gaan.

De effecten van binnengemeentelijke organisatie zijn niet eenduidig, voor zover er al kennis over beschikbaar is. Zo zijn effecten op de representatieve democratie niet gedocumenteerd en die op burgerparticipatie en gemeentelijke bestuurskracht sporadisch. De gemeentesecretarissen die de vragenlijst ingevuld hebben, zijn positiever dan wat we uit de literatuur ophalen. We kunnen niet uitsluiten dat er daadwerkelijk verbeteringen zijn opgetreden, evenmin als dat de respondenten een te rooskleurig beeld hebben.

\section{Reflectie op de uitkomsten}

Onze inventarisatie laat een groot aantal en een ruime variatie aan binnengemeentelijke organisatievormen zien; ten opzichte van eerdere onderzoeken lijkt er sprake te zijn van een toename. Kennelijk bestaat er een groeiende behoefte aan constructies die burger en bestuur bij de voorbereiding en uitvoering van beleid dichter bij elkaar brengen. Op de vraag waarom dat zo is, geeft het onderzoek dat we verrichtten geen direct antwoord. Het lijkt ons aannemelijk dat er een verband is met onder meer de grote decentralisaties in het sociale domein in de voorbije jaren, waardoor lokaal beleid vaker en directer van belang is voor burgers; wellicht groeit daarmee de behoefte aan een kleinere afstand tussen bestuur en burger. Mogelijk zorgt ook de gestaag toenemende omvang van gemeenten na enkele decennia van herindelingsgolven voor een groeiende behoefte aan een kleinschaligere organisatie van de voorbereiding en uitvoering van gemeentelijke taken (maar een significant verband hebben we hier niet kunnen vaststellen). Daarnaast is het voorstelbaar dat het werken met binnengemeentelijk organise- 
ren een antwoord is op onrust in de democratie en een zoektocht naar meer burgerbetrokkenheid.

Binnengemeentelijk organiseren gaat uit van de veronderstelling dat sommige activiteiten beter op kleinere schaal ondernomen kunnen worden: wijken, buurten of stadsdelen staan centraal, ongeacht de vorm van binnengemeentelijk organiseren. De veronderstelling lijkt te zijn, dat er op die kleinere schaal sprake is van een 'gemeenschap' én dat vraagstukken zich binnen die gemeenschap en die territoriale afgrenzing voordoen. Soortgelijke vooronderstellingen liggen ten grondslag aan het bestaan van decentraal bestuur als zodanig, althans: van het territoriaal georganiseerde bestuur.

Het is echter de vraag of die veronderstellingen nog wel correct zijn. Tal van onderwerpen, ook kwesties die naar hun aard lokaal zijn, trekken zich weinig aan van bestaande bestuurlijke grenzen (Van den Brink, 1992). Bij tal van maatschappelijke vraagstukken is sprake van schaaldifferentiatie (en dus niet alleen maar schaalverkleining of -vergroting): zij vragen dikwijls om aandacht op verschillende niveaus. Nog anders gezegd: de schaal van maatschappelijke vraagstukken, die van effectief bestuur en die van publieke betrokkenheid vallen niet langer samen (Franzke e.a., 2007; Schaap, 2015). Dat betekent, dat elke gebiedsindeling imperfect zal zijn; dat geldt voor bovenlokaal werken, maar evenzeer voor binnengemeentelijk organiseren. Binnengemeentelijk organiseren is dus niet per definitie de oplossing voor bestuurlijke schaalproblemen. Het impliceert ook dat besturen 'multi-level' en 'functioneel' geworden is. En dat heeft gevolgen voor de organisatie van de democratie: de democratische legitimatie exclusief via de representatieve weg is dan een probleem (Duchastel \& Canet, 2005: Hendriks e.a., 2017). Immers, het startpunt van beleidsvorming is dan niet langer het territorium, maar veeleer een maatschappelijk vraagstuk dat zich op tal van plaatsen kan manifesteren. Besluitvorming is zo niet langer voorbehouden aan de representatieve organen, maar vindt plaats in onderhandelingen tussen tal van (publieke en private) actoren. De traditionele democratie, met de volksvertegenwoordiging formeel als legitimerend besluitvormingsorgaan, sluit daar slecht bij aan.

Maar de lokale democratie in ons land is in essentie nog altijd een territoriaal georganiseerde, representatieve democratie. Volgens de organieke wetgeving heeft de raad daarin - vrijwel exclusief - de centrale rol. Hij is in beginsel het enige rechtstreeks verkozen orgaan en is belast met de voornaamste vertegenwoordigende, kaderstellende en controlerende taken. De raad wordt geacht in staat te zijn te formuleren hoe het algemeen belang van de gehele gemeenschap het best wordt gediend en daartoe richtinggevende besluiten te nemen. Maar door de grotere culturele diversiteit en sociale mobiliteit in veel lokale gemeenschappen, en door de toegenomen breedte en complexiteit van het gemeentelijke takenpakket, kan de raad deze centrale rol steeds moeilijker vervullen.

Tegelijkertijd vervullen ook wijk-, buurt- en dorpsraden, burgerfora, burgerbegrotingen en andere vormen van 'binnengemeentelijke democratie' aanvullende representatieve functies. Het wettelijke kader biedt gemeenten al veel ruimte om 
op dit gebied eigen arrangementen te ontwerpen, maar de keerzijde is dat datzelfde kader ook weinig houvast biedt. Belangrijk is dat steeds duidelijk moet zijn wat ieders rol is; men moet niet de suggestie van een (mee)beslissingsbevoegdheid laten ontstaan waar het strikt genomen slechts gaat om een adviserende rol.

Wij zien hier ruwweg twee mogelijkheden. De eerste is in de Gemeentewet bepalingen op te nemen over enkele concrete en regelmatig gebruikte binnengemeentelijke organisatievormen, zoals dorps- of wijkraden, of over meer directe vormen van burgerbetrokkenheid. De wet zou dan enkele hoofdregels kunnen geven over de wijze van samenstelling of 'aanwijzing', de bevoegdheden en de wijze waarop verantwoording wordt afgelegd. Die bevoegdheden zouden verder moeten gaan dan 'advisering': ook besluitvorming en de daaraan gekoppelde verantwoordelijkheid zouden aan binnengemeentelijke organen overgedragen moeten kunnen worden. Grondwet en organieke wetgeving zouden zo de mogelijkheid kunnen bieden om het gemeentelijk bestuur volgens verschillende modellen vorm te geven, waarbij verschillende regels voor de samenstelling van de gemeentelijke organen, hun werkwijze en de nodige verantwoordingsmechanismen kunnen gelden. De tweede mogelijkheid zou zijn dergelijke zaken niet als zodanig in de organieke wetgeving op te nemen, maar in de Gemeentewet te bepalen dat de raad en het college in elke gemeente gezamenlijk een statuut (of zo men wil, een constitutie) vaststellen waarin - vanzelfsprekend binnen de wettelijke grenzen - wordt aangegeven hoe binnen de gemeente de vertegenwoordigende, regelgevende en bestuurlijke taken in hoofdlijnen zijn georganiseerd en verdeeld, welke andere organen dan de hoofdorganen daarin een rol spelen, welke bevoegdheden daartoe worden toegekend en hoe verantwoording voor het gevoerde bestuur wordt afgelegd. De wet schrijft dan niet voor hoe de binnengemeentelijke organisatie eruit moet zien, maar dwingt raad en college wel om daarover zelf heldere gedachten te vormen en die gezamenlijk vast te leggen.

Hoe dan ook ligt het voor de hand de wetgeving beter aansluiting te laten vinden bij de gegroeide praktijk. Die praktijk van de lokale democratie is er een van meervoudigheid (zie ook het rapport van de Commissie Toekomstgericht lokaal bestuur van de VNG, 2016). In diverse gemeenten, zo niet alle, is de vertegenwoordigende democratie aangevuld met vormen van participatieve, doe- en directe democratie. In aanvullende vormen van democratie kunnen burgers een veel actievere rol hebben. Momenteel is de ruimte voor die actievere rol echter beperkt tot het mogen adviseren van het gemeentebestuur. Zelf besluiten nemen gebeurt mondjesmaat, bijvoorbeeld in geval van buurtbudgetten. Ook zijn nogal wat van deze vormen territoriaal georganiseerd, terwijl, zoals we in de vorige paragraaf betoogden, er behoefte is aan meer 'functionele' vormen van bestuur (en dus van democratie en burgerbetrokkenheid).

\section{Afsluiting}

In het voorgaande hebben we het binnengemeentelijk organiseren beschouwd in het bredere kader van ontwikkelingen in de publieke sector. Ons pleidooi gaat daarbij twee kanten op. In de eerste plaats pleiten wij ervoor dat binnengemeen- 
telijk organiseren niet alleen territoriaal opgepakt wordt, maar zeker ook functioneel, en wel omdat vraagstukken zich meestal weinig van territoriale grenzen aantrekken. Dit is een pleidooi aan het adres van de gemeente, maar ook aan die van de wetgever: verdergaande overdracht van bevoegdheden en verantwoordlijkheden aan functionele vormen van (binnengemeentelijk) bestuur lijkt noodzakelijk. In de tweede plaats pleiten wij voor verruiming van de opvattingen over de democratie. De representatieve democratie behoeft aanvulling met vormen van participatieve en directe democratie, en wel zodanig dat ook besluitvormingsmacht kan worden overgedragen. Beide pleidooien grijpen in elkaar: functionele vormen van bestuur laten zich lastig legitimeren door middel van verkiezingen voor vertegenwoordigende organen. Dan komen andere vormen van democratie zeer van pas.

\section{Literatuur}

Bäck, H., G. Gjelstrup, M. Helgesen, F. Johansson \& J.E. Klausen, Urban political decentralization. Six Scandinavian cities, Wiesbaden: 2005.

Berenschot, Binnengemeentelijke decentralisatie en deconcentratie in kaart gebracht, Utrecht: februari 2001.

Bihari, M., Gemeentelijke deconcentratie en decentralisatie, Rotterdam: 2008.

Boluijt, B., G. Drosterij \& F. Hendriks, 'Omgaan met botsende verwachtingen: Burgers aan Zet! In Dordrecht', F. Hendriks \& G. van Drosterij (eds.), De zucht naar goed bestuur in de stad, Den Haag: 2012, p. 31-47.

Boogers, M.J.G.J.A. \& G.H. Reussing, Decentralisatie, schaalvergroting en lokale democratie. Samenvattend onderzoek naar gevolgen voor rollen en posities van lokale bestuurders en naar gevolgen voor bestuurskracht en democratie, Universiteit Twente, Enschede: 2018.

Brenninkmeijer, A.F.M., A.J. Kruiter, J. de Vries, M.J.W. van Twist \& Y.M. van der Vlugt, Amsterdam 2020. Advies- en evaluatiecommissie bestuurlijk stelsel, Amsterdam: 2016.

Brink, H. van den, 'Democratie zonder grenzen', H. van den Brink (ed.), Bestuur en territoir. Opstellen aangeboden aan drs. A. Bours, Amsterdam: 1992, p. 33-43.

Cachet, A., M.A. Beukenholdt-ter Mors, H.H.F.M. Daemen, A.B. Ringeling \& L. Schaap, 'Binnengemeentelijk gedecentraliseerd. Een kleinere raad?', Openbaar Bestuur, 11 november 2003, p. 16-20.

Commissie Toekomstgericht lokaal bestuur, Op weg naar meervoudige democratie, Den Haag: 2016.

$\mathrm{CPB}$, De wijkteambenadering nader bekeken. Het effect van de inzet van wijkteams op Wmozorggebruik, Centraal Planbureau, Den Haag: 2019.

Denters, S.A.H. \& P.J. Klok, 'Dorps- en wijkraden in Europa', Bestuurswetenschappen, 2013/5-6, p. 72-93.

Dordrecht, Raadsinformatie inzake Evaluatie experimenten met buurtbudgetten Burgers aan Zet, kenmerk MO/523633, gemeente Dordrecht, Dordrecht: 1 maart 2011.

Duchastel, J. \& R. Canet, 'The transformation of citizenship and democracy at local and global levels', P. Booth \& B. Jouve (eds.), Metropolitan democracies. Transformations of the state and urban policy in Canada, France and Great Britain, Hampshire: 2005, p. 13-31.

Ecorys, Business case Wijkteams Rotterdam 2016. Eindrapport, Rotterdam: 26 mei 2016.

Franzke, J., M.J.G.J.A. Boogers, J.M. Ruano \& L. Schaap (eds.), Tensions between local governance and local democracy, Den Haag: 2007. 
Gilsing, R. \& N. Hermens, Eindevaluatie Wijkteams Jeugd Tiel, Utrecht: 2016.

Hakvoort, J.L.M., Territoriale decentralisatie, Assen: 1980.

Hendriks, F., S. van Zuydam \& K.H.J. van der Krieken, 'Democratische politiek: "minder, minder, minder" of anders?', Res Publica, 2017/1, p. 7-34.

Klok, P.J., S.A.H. Denters \& M.J. Oude Vrielink, Wijkcoaches in Velve-Lindenhof. Overkoepelende Eindrapportage, Enschede: juni 2012.

Konijnenbelt, W., 'Medebewindsverordeningen en het vraagstuk van delegatie aan B\&W', De Gemeentestem, 2013/102.

Koster, Y. de, 'Wijkteams jeugdhulp moeten op de schop', Binnenlands Bestuur, 30 januari 2018.

Lammerts, R. \& R. Verwijs, Deelnemen aan wijkraden. Verwachtingen, motieven en ervaringen van bewoners over participatie in wijkraden, Utrecht: juli 2009.

Loorbach, D., M.W. van Buuren, F. van Steenbergen, C. van Leeuwen, S. Rach, H. Bil, K. Schipper, S. Munneke \& M.A. van der Steen, Een kwestie van kiezen. Naar een complementaire democratie voor alle Rotterdammers, onderzoeksrapport Evaluatie Bestuurlijk Model Rotterdam 2016, Rotterdam/Groningen: 2016.

Michiels, F.C.M.A., Hoofdzaken van het bestuursrecht, Alphen aan den Rijn: 2016.

Movisie, Evaluaties van sociale wijkteams. Inventarisatie van afgesloten onderzoeken van sociale wijkteams, Utrecht: 20 februari 2014.

Movisie, Sociale (wijk)teams opnieuw uitgelicht. Derde landelijke peiling onder gemeenten (zomer 2017), Utrecht: januari 2018.

Necker van Naem, Dorps- en wijkraden in Nederland, Utrecht: maart 2013.

Reussing, G.H., 'Onderzoek naar binnengemeentelijk bestuur. Ervaringen van de vorige generatie', Bestuurswetenschappen, 2013/5-6, p. 39-54.

Schaap, L., Lokaal bestuur, Dordrecht: 2015.

Schaap, L. \& G.J. Leenknegt, Kleinschalig \& Kleurrijk. Binnengemeentelijke organisatie geïnventariseerd, Tilburg: 2018.

Schaap, L., W. Blijleven, F. Hendriks, D.J. Jacobs, N. Karsten, J.J.C. van Ostaaijen \& C. Wagenaar, Ambitie \& Ambivalentie. Vernieuwing van de lokale democratie in Nederland, Tilburg: 2018.

Schaap, L., F. Hendriks, A. Frankowski \& J.J.C. van Ostaaijen, 'Kleinschaliger besturen binnen de stad. Binnengemeentelijke decentralisatie, nieuwe stijl?', Bestuurswetenschappen, 2013/5-6, p. 115-138.

Schuilenburg, M.B., 'Buurt bestuurt niet', Proces. Tijdschrift voor strafrechtspleging, 2017/1, p. 19-34.

Utrecht, Evaluatie pilot buurtbudgetten. 'De eerste stap is gezet', Utrecht: 2016.

Utrecht, Werkwijzen Utrecht maken we samen, Utrecht: 2018.

Woude, W. van der, 'Commentaar bij artikel 128 van de Grondwet, E.M.H. Hirsch Ballin \& G.J. Leenknegt (eds.), Artikelsgewijs commentaar op de Grondwet, webeditie 2019 (www.Nederlandrechtsstaat.nl).

WRR, Binnengemeentelijke decentralisatie en deconcentratie in Amsterdam, Rotterdam, Den Haag en Utrecht. Een inventarisatie, Wetenschappelijke Raad voor het Regeringsbeleid, Den Haag: 1998.

WRR, Buurtinitiatieven en buurtbeleid in Nederland anno 2004, Wetenschappelijke Raad voor het Regeringsbeleid, Den Haag: 2004. 